\title{
Risk Factors and the Incidence of Low Birth Weight in Dr Slamet Garut Hospital 2019
}

\author{
$1^{\text {st }}$ Evi Kusumahati \\ Sekolah Tinggi Ilmu Kesehatan \\ 'Aisyiyah Bandung \\ Indonesia \\ evikusumahati@yahoo.co.id
}

\author{
$2^{\text {nd }}$ Santy Sanusi \\ Sekolah Tinggi Ilmu Kesehatan \\ 'Aisyiyah Bandung \\ Indonesia
}

\begin{abstract}
Background: Low Brith Weight (LBW) is still a significant public health problem. The high incidence of LBW may affect the quality of human resources in the future, since babies born with LBW may also cause an increased risk of permanent disability, cognitive impairment and other chronic health problems in the future. Identification of $\mathrm{LBW}$ risk factors is essential in mediating the health consequences of LBW after birth and also in reducing the incidence of $\mathrm{LBW}$. This study aims to the risk factors and the incidence of $\mathrm{LBW}$ in DR.Slamet Garut Hospital. Methods: This study was a retrospective analytic survey with cross-sectional design, using secondary data, collected from medical records of DR.Slamet Garut Hospital from January1st to December 31st 2019. The sample was 1582 of unabridged birth from a population that met the inclusion criteria. Data were analyzed by univariate, bivariate with chi-square and multivariate test with multiple logistic regressions. Result: The incidence of $L B W$ were $19,6 \%$. The result of bivariate analysis showed significant relationship between gestasional age $(p=0,000 ; O R=77,055)$, twin pregnancy $(p=0,000 ; O R=21,387)$, eclampsia $(p=0,002$; $\mathrm{OR}=3,310)$, preeclampsia $\quad(\mathrm{p}=0,010 ; \quad \mathrm{OR}=1,836), \quad \mathrm{HB}$ $(P=0,014 ; O R=1,668)$ and education $(p=0,044 ; O R=1,640)$ with LBW. Gestational age is the most dominant factor causing LBW after controlled by other variable. Conclusion: The incidence of LBW in DR Slamet Garut Hospital in 2019 was still high, with the most dominant factor is gestational age. Need to develop a model of early detection LBW at the community level by reference to the risk factors found in every health care unit in Garut
\end{abstract}

Keywords—Risk Factors, Incidence, Low Birth Weight

\section{INTRODUCTION}

LBW is one of the risk factors that have contributed to infant mortality, especially during the perinatal period [1]. LBW has a large impact on children's growth and development in the future. The impact of low birth weight babies is growth will be slow, tendency to have a lower intellectual appearance than babies of average birth weight. Also, LBW infants can experience mental and physical disorders at a later age of development and thus require high maintenance costs [2].
WHO reports, babies with low birth weight contribute as much as 60 to $80 \%$ of all neonatal deaths and have a risk of death 20 times greater than babies with average weight. Based on WHO and UNICEF data in 2015, around 22 million babies were born in the world, of which $16 \%$ were born with Low Birth Weight Babies [3]. The LBW percentage in developing countries is $16.5 \%$, twice that of developed countries (7\%). Indonesia is a developing country that ranks third as the country with the highest prevalence of LBW (11.1\%), after India (27.6\%) and South Africa (13.2\%). Besides Indonesia also became the second country with the highest prevalence of LBW among other ASEAN countries, after the Philippines $(21.2 \%)$ [4]

Based on IDHS data, LBW figures in Indonesia are around $7.5 \%$. This figure is higher than the LBW target set in the target of the Nutrition Improvement Program Towards Healthy Indonesia, which is a maximum of $7 \%$. The results of Riskesdas in 2015 stated that the percentage of children under five (0-59 months) with LBW in Indonesia was $10.2 \%$. The LBW incidence rate in West Java is still above the national average of $10.8 \%$ or as many as 18,997 events [5]. Dr.Slamet Regional General Hospital, is one of the hospitals for referral of major obstetric cases in Garut Regency. Data obtained from Dr.Slamet Garut General Hospital from 2015-2017 sequentially showed LBW incidence rates of $14.3 \%$, $16.2 \%$ and $17.7 \%$ [6]. Based on the data above, the incidence of LBW in RSUD Dr.Slamet Garut in the last three years tends to increase.

\section{METHOD}

This study uses a retrospective analytic survey research design with the cross-sectional approach. The study population was all births at the Dr.Slamet Garut Regional Hospital from August to December 2019 using secondary data from medical record installations. Samples were taken from populations that met the inclusion criteria of 1582 births. Sampling with a total sampling technique. The dependent variable of this study was LBW and the independent variables observed were maternal age, 
gestational age, parity, HB level, history of abortion, history of preeclampsia and eclampsia, history of diabetes mellitus, history of multiple pregnancies, fetal sex, education and mother's occupation. Data analysis was performed to determine the relationship between maternal characteristics and LBW events. Data analysis in this study uses univariate analysis, bivariate with chi- square and multivariate with multiple logistic regression using the Backward LR method to see the most influential risk factors with LBW events then interpreting the results of the analysis and making an equation model.

\section{RESULTS AND DISCUSSION}

TABLE I. FREQUENCY DISTRIBUTION OF SEVERAL LBW RISK FACTORS

\begin{tabular}{|c|c|c|}
\hline \multirow[t]{2}{*}{ Characteristics of Mother } & \multicolumn{2}{|c|}{ total } \\
\hline & $\mathbf{n}$ & $\%$ \\
\hline \multicolumn{3}{|l|}{ Mother's age } \\
\hline$<20$ years old & 132 & 8.3 \\
\hline 20-35 years old & 1193 & 75.4 \\
\hline$>35$ years old & 257 & 16.2 \\
\hline \multicolumn{3}{|l|}{ Age of Pregnancy } \\
\hline Preterm & 313 & 19.8 \\
\hline Atter & 1258 & 79.5 \\
\hline Posterm & 11 & 0.7 \\
\hline \multicolumn{3}{|l|}{ Parity } \\
\hline Primipara & 634 & 40.1 \\
\hline Multipara & 894 & 56.5 \\
\hline Grandemultipara & 54 & 3,4 \\
\hline \multicolumn{3}{|l|}{ HB levels } \\
\hline$<11$ gr\% (anemia) & 732 & 47.7 \\
\hline$>11 \mathrm{gr} \%$ (no anemia) & 803 & 52.3 \\
\hline \multicolumn{3}{|l|}{ Abortion history } \\
\hline There is & 170 & 10.7 \\
\hline There is no & 1412 & 89.3 \\
\hline \multicolumn{3}{|l|}{ Preeclampsia } \\
\hline There is & 427 & 27 \\
\hline There is no & 1155 & 73 \\
\hline \multicolumn{3}{|l|}{ Eclampsia } \\
\hline There is & 76 & 4,8 \\
\hline There is no & 1506 & 95.2 \\
\hline \multicolumn{3}{|l|}{ Double pregnancy } \\
\hline Double & 64 & 4 \\
\hline Single & 1518 & 96 \\
\hline \multicolumn{3}{|l|}{ Gender } \\
\hline Male & 801 & 50.6 \\
\hline Girl & 781 & 49.4 \\
\hline \multicolumn{3}{|l|}{ Diabetes mellitus } \\
\hline There is & 4 & 03 \\
\hline There is no & 1578 & 99.7 \\
\hline \multicolumn{3}{|l|}{ last education } \\
\hline Not school (TS) & 6 & 0.4 \\
\hline Elementary school & 121 & 8.0 \\
\hline Middle School & 176 & 11.6 \\
\hline High school & 1177 & 77.4 \\
\hline D3 & 15 & 1,0 \\
\hline S1 & 25 & 1.6 \\
\hline \multicolumn{3}{|l|}{ Profession } \\
\hline Housewife & 1456 & 92 \\
\hline College student & 2 & 0.1 \\
\hline Student & 7 & 0.4 \\
\hline Labor & 3 & 0.2 \\
\hline Farmers & 21 & 1,3 \\
\hline General employees & 51 & 3,2 \\
\hline entrepreneur & 13 & 0.9 \\
\hline Teacher & 9 & 0.6 \\
\hline Nakes & 4 & 0.3 \\
\hline Civil servants & 16 & 1,0 \\
\hline
\end{tabular}


TABLE II. BIVARIATE ANALYSIS OF FACTORS THAT INFLUENCE THE INCIDENCE OF LBW IN RSUD DR.SLAMET GARUT

\begin{tabular}{|c|c|c|c|c|c|c|c|c|}
\hline \multirow{4}{*}{ Risk factor } & \multicolumn{7}{|c|}{ REGENCY } & \\
\hline & \multicolumn{4}{|c|}{ Baby Birth Weight } & & & & \\
\hline & \multicolumn{2}{|c|}{ LBW } & \multicolumn{2}{|c|}{ BBLN } & \multicolumn{2}{|c|}{ total } & \multirow[t]{2}{*}{$\mathbf{p}$} & \multirow[t]{2}{*}{$\mathbf{R p}$} \\
\hline & $\mathbf{n}$ & $\%$ & $\mathbf{n}$ & $\%$ & $\mathbf{n}$ & $\%$ & & \\
\hline \multicolumn{9}{|l|}{ Mother's age } \\
\hline$<20$ years old & 26 & 19.7 & 106 & 80.3 & 132 & 100 & 1,000 & $1,011(0,643-1,588)$ \\
\hline $20-35$ years old & 233 & 19.5 & 960 & 80.5 & 1193 & 100 & .993 & \\
\hline$>35$ years old & 51 & 19.8 & 206 & 80.2 & 257 & 100 & 0.977 & $1,020(0.727-1,431)$ \\
\hline \multicolumn{9}{|l|}{ Age of Pregnancy } \\
\hline Preterm & 248 & 79.2 & 65 & 20.8 & 313 & 100 & $0,000 *$ & $\begin{array}{l}74,869 \\
108.96)\end{array}$ \\
\hline Atter & 61 & 4,8 & 1179 & 95.2 & 1258 & 100 & $0,000 *$ & \\
\hline Posterm & 1 & 9.1 & 10 & 90.9 & 11 & 100 & 0.025 & $\begin{array}{ll}1,962 & (0,274- \\
15,577) & \\
\end{array}$ \\
\hline \multicolumn{9}{|l|}{ Parity } \\
\hline Primipara & 106 & 16.7 & 528 & 83.3 & 634 & 100 & $0.019 *$ & \\
\hline Multipara & 188 & 21.0 & 706 & 79.0 & 894 & 100 & $0.041 *$ & $1,326(1,019-1,726)$ \\
\hline Grandemultipara & 16 & 29.6 & 38 & 70.4 & 54 & 100 & $0.028 *$ & $2,097(1,128-3,900)$ \\
\hline \multicolumn{9}{|l|}{ HB levels } \\
\hline$<11 \mathrm{gr} \%$ (anemia) & 183 & 25.0 & 549 & 75.0 & 732 & 100 & $0,000 *$ & 1,861 \\
\hline$>11 \mathrm{gr} \%$ (no anemia) & 122 & 15.2 & 681 & 84.8 & 803 & 100 & & $(0.928-1,966)$ \\
\hline \multicolumn{9}{|l|}{ Abortion history } \\
\hline There is & 41 & 24.1 & 129 & 75.9 & 170 & 100 & $.142 * *$ & 1,350 \\
\hline There is no & 269 & 19.1 & 1143 & 80.9 & 1412 & 100 & & $(0.928-1,966)$ \\
\hline \multicolumn{9}{|l|}{ Preeclampsia } \\
\hline There is & 104 & 24.4 & 323 & 75.6 & 427 & 100 & $0.005 *$ & 1,483 \\
\hline There is no & 206 & 17.8 & 949 & 82.2 & 1155 & 100 & & $(1,135-1,938)$ \\
\hline \multicolumn{9}{|l|}{ Eclampsia } \\
\hline There is & 36 & 47.4 & 40 & 52,6 & 76 & 100 & $0,000 *$ & 4,047 \\
\hline There is no & 274 & 18.2 & 1232 & 81.8 & 1506 & 100 & & $(2,532-6,468)$ \\
\hline \multicolumn{9}{|l|}{ Double pregnancy } \\
\hline Double & 2 & 50.0 & 2 & 50.0 & 4 & 100 & $.174 * *$ & 4,123 \\
\hline Single & 308 & 19.5 & 1270 & 80.5 & 1578 & 100 & & $(0.579-29,388)$ \\
\hline \multicolumn{9}{|l|}{ Gender } \\
\hline Male & 51 & 79.7 & 13 & 20.3 & 64 & 100 & $0,000 *$ & 19,070 \\
\hline Girl & 259 & 17.1 & 1259 & 82.9 & 1518 & 100 & & $(10,223-35,573)$ \\
\hline \multicolumn{9}{|l|}{ Diabetes mellitus } \\
\hline There is & 162 & 20.7 & 619 & 79.3 & 781 & 100 & .284 & 1,155 \\
\hline There is no & 148 & 18.5 & 653 & 81.5 & 801 & 100 & & $(0.901-1.480)$ \\
\hline \multicolumn{9}{|l|}{ last education } \\
\hline Low education & 85 & 28.1 & 218 & 71.9 & 303 & 100 & $0,000 *$ & 1,870 \\
\hline TS, SD, SMP & & & & & & & & $(1,397-2,502)$ \\
\hline Higher education & 210 & 17.3 & 1007 & 82.7 & 1217 & 100 & & \\
\hline \multicolumn{9}{|l|}{ SMA, D3, S1 } \\
\hline \multicolumn{9}{|l|}{ Profession } \\
\hline $\begin{array}{l}\text { Work } \\
\text { (labour, private, etc.) }\end{array}$ & 24 & 20.5 & 93 & 79.5 & 117 & 100 & 0.890 & 1,064 \\
\hline $\begin{array}{l}\text { Does not work } \\
\text { (Students, students, } \\
\text { IRT) }\end{array}$ & 286 & 19.5 & 1179 & 80.5 & 1465 & 100 & & $(0.667-1,697)$ \\
\hline
\end{tabular}

Information :

* significant, p-value $<0.05$

$* *$ p-value $<0.25$

Based on the results of the study, there was a statistically significant relationship between gestational age, parity, HB levels, preeclampsia, eclampsia, multiple pregnancies and maternal education on LBW events.

There was no significant relationship between maternal age, diabetes mellitus, baby sex and maternal occupation with LBW events. 
Candidate variables that meet the multivariate model candidate criteria are statistically significant variables $(\mathrm{p}$ $<0.05$ ) and variables that have a value of $\mathrm{p}<0.25$, including: gestational age, parity, HB levels, history of abortion, history of preeclampsia, history of eclampsia, diabetes mellitus, multiple pregnancy and maternal education. Presented in the following table:

TABLE III. THE INITIAL AND FINAL MODEL OF MULTIVARIATE ANALYSIS OF FACTORS INFLUENCING THE INCIDENCE OF LBW IN RSUD DR.SLAMET GARUT

\begin{tabular}{|c|c|c|c|c|c|}
\hline Variable & & Early model & & & \\
\hline & p-value & OR $(95 \%$ CI $)$ & Coefficient & p-value & OR $(95 \% \mathrm{CI})$ \\
\hline Maternal gestational age & 0,000 & $79,154(51,299-122,133)$ & 4,345 & 0,000 & $77,055(50,276-118,099)$ \\
\hline Double pregnancy & 0,000 & $22,222(9,033-54,667)$ & 3,063 & 0,000 & $21,387(8,879-51,515)$ \\
\hline Diabetes mellitus & 0.468 & $3,374(0,127-89,698)$ & & & \\
\hline eclampsia & 0.003 & $3,200(1,487-6,886)$ & 1,197 & 0.002 & $3,310(1,545-7,088)$ \\
\hline Preeclampsia & 0.009 & $1,860(1,167-2,963)$ & .608 & 0.010 & $1,836(1,159-2,909)$ \\
\hline Mother's education & 0.034 & $1,698(1,040-2,772)$ & 0.495 & 0.044 & $1,640(1,012-2,568)$ \\
\hline HB levels & 0.014 & $1,663(1,106-2,500)$ & 0.512 & 0.014 & $1,668(1,111-2,504)$ \\
\hline Parity & 0.475 & $0.856(0.559-1.311)$ & & - & \\
\hline Abortion history & 0.570 & $0.833(0.443-1.564)$ & & - & \\
\hline constant & $\mathbf{0 , 0 0 0}$ & 0.025 & -3800 & & 0.022 \\
\hline
\end{tabular}

The results of multivariate analysis showed the final model of variables that proved to be very influential on LBW events were gestational age, multiple pregnancy, preeclampsia, eclampsia, HB levels and maternal education.

The LBW event equation equations are as follows:

\section{LBW incidence $=-3,800+4,345$ (gestational age) $+3,063$ (twin pregnancy) $+1,197$ \\ $($ eclampsia $)+0,608$ (preeclampsia) $+0.512($ HB levels $)+0.495$ (education)}

\section{A. Discussion}

The results of the study found that the incidence of low birth weight (LBW) in RSUD Dr.Slamet Garut in the period August-December 2019 was 19.6\%, higher than global events $(16 \%)$, developing countries $(19 \%)$ and Indonesia $(10 \%, 3 \%$, ) This figure is greater than the LBW target set in the nutrition improvement program target for Healthy Indonesia in 2010 of $7 \%$. The high incidence of LBW can be influenced by multi factors, including gestational age, haemoglobin levels, preeclampsia, eclampsia, multiple pregnancy and maternal education

\section{B. Gestational Age}

Pregnancy at birth is the most significant determinant of newborn weight. Gestational age affects the maturation of the person and the effectiveness of the distribution of nutrients and premature birth and babies with low birth weight. According to researchers, the development of the role and function of the baby's organs in line with maternal gestational age. The more mature the gestational age, the more perfect the development of the baby's organs, so that the baby is better equipped to survive outside the womb. Regular gestational age is also influenced by nutrient intake during pregnancy [7]. At each stage of the pregnancy process, a pregnant woman needs nutritional food with different nutritional content and adjusted to the development of the fetus and the condition of the mother's body. Therefore monitoring and monitoring of the condition of the mother at each stage of pregnancy is essential so that the mother and baby are born healthy [8].

\section{Double Pregnancy}

LBW is the result of premature birth and or poor fetal growth. Both are common in multiple pregnancies. In a multiple pregnancy the blood supply to the fetus is divided into two or more for each fetus so that the supply of nutrients is reduced.

\section{History of Preeclampsia and Eclampsia}

Preeclampsia is a risk factor for LBW with an incidence of $24.4 \%$ of all deliveries at RSUD Dr Slamet Garut, it is known that there is a significant relationship between preeclampsia and LBW events. The results of this study are in line with Kurniawati's research which shows that there is a significant relationship between preeclampsia and LBW birth, where the chance of LBW birth is 3.25 times higher than without preeclampsia.

\section{E. Haemoglobin levels}

Lack of $\mathrm{Hb}$ levels in pregnant women is one of the health problems that is susceptible to occur during pregnancy, $\mathrm{Hb}$ levels $<11 \mathrm{~g} / \mathrm{dl}$ indicate that pregnant women suffer from anemia. Anaemia in pregnant women increases the risk of LBW, the risk of bleeding before and during labour, it can even cause the death of the mother and baby if the pregnant woman suffers from severe anaemia. This can contribute greatly to maternal mortality and infant mortality[9].

In the physiological state of pregnancy, $\mathrm{Hb}$ and erythrocyte concentrations will increase, however increase will slow down in mid-pregnancy so that the $\mathrm{Hb}$ concentration will decrease in following with an increase in blood volume and become very low in the fifth and seventh months of pregnancy, Ministry of Health Data of RI, 2012 shows that more than $50 \%$ of pregnant women 
suffer from anaemia, with most of the causes being iron deficiency needed for haemoglobin formation[10]

\section{CONCLUSIONS}

There is a significant relationship between gestational age, parity, HB levels, preeclampsia, eclampsia, multiple pregnancies and maternal education on LBW events. There was no significant relationship between maternal age, diabetes mellitus, baby sex and maternal occupation with LBW events. The most dominant variable influencing the incidence of LBW is gestational age (OR $=77,055 ; 95 \%$ CI 50,276-118,099)

\section{REFERENCES}

11] L. C. De Jesus et al., "Outcomes of small for gestational age infants born at< 27 weeks' gestation," J. Pediatr., vol. 163, no. 1, pp. 55-60, 2013.

[2] A. Proverawati and C. Ismawati, "BBLR (berat badan lahir rendah)," Yogyakarta Nuha Med., vol. 61, 2010.

[3] L. Liu et al., "Global, regional, and national causes of child mortality: an updated systematic analysis for 2010 with time trends since 2000," Lancet, vol. 379, no. 9832, pp. 2151-2161, 2012.

[4] S. Supiati, "Karakteristik Ibu Kaitannya Dengan Kejadian Bayi Berat Badan Lahir Rendah," J. Kebidanan dan Kesehat. Tradis., vol. 1, no. 1, pp. 64-68, 2016.

[5] B. P. Statistik, "Survei demografi dan kesehatan Indonesia 2016," Jakarta Badan Pus. Stat., 2017.

[6] RS. Dr Slamet Garut, "Medical Record 2017," Garut, 2017.

[7] J. Katz et al., "Mortality risk in preterm and small-forgestational-age infants in low-income and middle-income countries: a pooled country analysis," Lancet, vol. 382, no. 9890, pp. 417-425, 2013

[8] W. H. Organization, "Global nutrition targets 2025: childhood overweight policy brief," World Health Organization, 2014.

[9] D. Kim and A. Saada, "The social determinants of infant mortality and birth outcomes in Western developed nations: a cross-country systematic review," Int. J. Environ. Res. Public Health, vol. 10, no. 6, pp. 2296-2335, 2013.

[10] B. Penelitian, "Riset kesehatan dasar (Riskesdas) 2013," L. Nas, vol. 2013, no. 1, p. 384, 2013 